Тимчук， Л. \& Микитейчук， Х. (2019). Потенціал освіти дорослих у сфері соціальної \& Education

๑) SW\&E, 2019

\author{
УДК 352:364.62
}

DOI: $10.25128 / 2520-6230.19 .3 .9$

\section{Христина Микитейчук,} асистент, кафедра педагогіки та дошкільної освіти, Чернівецьвий національний університет імені Юрія, м. Чернівиі, Україна k.mykyteichuk@chnu.edu.ua

Article history:

Received: March 27, 2019

1st Revision: July 21, 2019

Accepted: September 30, 2019 роботи. Social Work and Education. Vol. 6, No. 3. Ternopil-Aberdeen, $2019 . \quad$ pp. 316-329. DOI: $10.25128 / 2520-6230.19 .3 .9$

ПОТЕНЦАЛ ОСВІТИ ДОРОСЛИХ У СФЕРІ СОЦІАЛЬНОЇ РОБОТИ

\begin{abstract}
АНОТАЦІЯ. Розкрито потенційні можливості освіти дорослих як ресурсу соціальної роботи. На основі короткої історичної ретроспективи висвітлено досвід використання освіти дорослих як превентивного засобу вирішення соціальних проблем. Розкрито зміст соціальних функцій освіти дорослих (адаптаційна, інформаційна, розвивальна, компенсаторна). На їх основі охарактеризовано види й форми освіти дорослих (додаткова або розвиваюча, компенсаторна, адаптуюча, випереджаюча; постбазова, модернізуюча, оновлююча, відновлююча). Конкретизовано й охарактеризовано сфери реалізації соціальних функцій освіти дорослих, представлений дайджест окремих діючих в Україні на даний момент освітніх пропозицій для дорослого населення.
\end{abstract}

Ключові слова: соціальна робота; освіта дорослих; формальна освіта; неформальна освіта; соціальні функції освіти дорослих. 


\section{Вступ}

Концепція навчання протягом усього життя і освіта дорослих як іiі основна стратегія $\epsilon$ наріжним каменем сучасних процесів становлення демократичної, правової, соціальної держави, оновлення соціально-економічних і духовних умов розвитку українського суспільства.

У сучасній міжнародній термінології освіта дорослих трактується як «комплекс поступових процесів формального чи іншого навчання, за допомогою яких люди, які $\epsilon, 3$ точки зору суспільства, якому вони належать, дорослими, розвивають свої здібності, збагачують свої знання і удосконалюють технічні та професійні кваліфікації чи застосовують їх у новому напрямі для задоволення своїх потреб і потреб свого суспільства» (Гамбурзька Декларація про навчання дорослих, 1997).

Необхідність упровадження освіти впродовж життя зумовлена зрушеннями в усіх сферах життєдіяльності, пов'язаними зі змінами в технологіях, упровадженням нової техніки, розвитком світового ринку 3 високим рівнем конкуренції між країнами. Для України актуальність освіти дорослих зумовлена додатковими чинниками, серед яких: необхідність адаптації дорослого населення до нових соціально-економічних умов; проблема зайнятості економічно активного населення; зростання безробіття; втрата необхідного рівня кваліфікації різними категоріями молоді та дорослих; зростання кількості функціонально неграмотних дорослих; суттєве старіння населення країни; посилення внутрішньо міграційних процесів.

Суттєвою перевагою освіти дорослих $є$ іï потенціал як ресурсу соціальної роботи - унікального виду діяльності 3 надання допомоги різним верствам населення, які перебувають у складному матеріальному i психологічному становищі. Соціальна робота $є$ суспільним амортизатором, спрямованим на підтримку i забезпечення соціального миру i рівноваги в суспільстві, попередження соціальних конфліктів, нейтралізацію дестабілізуючих факторів. Збільшення кризових явищ, які характеризують сучасність, зумовлює дезорієнтацію і неспроможність людей адаптуватися до нових життєвих ситуацій.

Освіта дорослих, яка пропонує гнучкі й різноманітні форми задоволення освітніх потреб дорослих, здатна формувати в них здатність жити в сучасному динамічно змінюваному суспільстві, адекватно сприймати такі зміни і перетворювати їх.

\section{Аналіз останніх публікацій}

Освіта дорослих як фактор соціальної адаптації i соціального захисту дорослого населення висвітлюється у працях Н. Бідюк, Н. Бичкової, Н. Єрмак, Т. Кононигіної, С. Лебедєвої, Л. Лук’янової, . Міннігалєвої, . Новікової, 
К. Приходько, I. Сагун. С. Архипова здійснила фундаментальне дослідження теоретико-методичних основ освіти соціально незахищених категорій дорослих, обгрунтувала специфіку професійної підготовки фахівців відповідного напряму (Архипова, 2017). Освіту дорослих як сферу соціальної практики розглядають автори навчальних посібників з андрагогіки І. Колесникова, Т. Браже, А. Марон, Н. Василенко, В. Вершиніна (Основы андрагогики, 2003).

Розкриттю прикладних можливостей освіти дорослих у вирішенні різних соціальних проблем присвячений окремий розділ колективної монографії «Освіта дорослих у перспективі змін: інновації, технології, прогнози» (за ред. А. Василюк, А. Стоговського), підготовлений польськими дослідниками. Зокрема, М. Бяласа обгрунтував значення навчання дорослих у контексті спеціальної педагогіки; А. Стоговський дослідив проблему ліквідації неграмотності у дорослих іноземців та їх інтеграції в іншомовне середовище; А.Чабанський порушив проблему освіти дорослих як знаряддя запобігання самогубств. Група авторів (А. Бляха, А. Брожек, К. Мацьковяк, М. Новицький, А. Плочінічак) проаналізували можливості використання освіти дорослих у сфері профілактики і охорони здоров'я (Освіта дорослих, 2017).

Метою даної публікації $\epsilon$ розкрити точки перетину освіти дорослих $\mathrm{i}$ соціальної роботи на основі рефлексії історичних аргументів та вивчення сучасних освітніх пропозицій для дорослого населення.

\section{Методологія дослідження}

У контексті дослідження ми: використовували загальнонаукові методи синтезу, аналізу, порівняння й узагальнення; здійснювали пошук інформації, аналізували повнотекстові наукові праці, розміщенні у наукометричній базі Google Scholar.

\section{Основна частина}

Історія розвитку людської цивілізації свідчить, що століттями соціальна робота носила характер філантропічної допомоги людині в складній життєвій ситуації, розвивалася як певна система матеріального забезпечення населення 3 метою створення належних умов для виживання в складні періоди. Водночас традиційна матеріальна підтримка потребуючих не вирішувала, а почасти ускладнювала соціальну ситуацію, породжуючи різні соціальні патології (наприклад, професійне жебрацтво), що змушувало шукати моделі допомоги не тільки оперативного, але й превентивного характеру. Серед таких у XIX століття були визнані виховання і освіта. «Якщо бідному хочуть надати справжню допомогу, то майже завжди його насамперед треба виховати. ... Найкращим 
засобом проти бідності завжди була освіта, - справжня освіта, яка рівномірно удосконалює тіло і душу, розум і серце», - до такого висновку приходить відомий німецький економіст Вільгельм Рошер (1895, с.44).

У світовій історії накопичений багатий досвід використання освіти дорослих як засобу й механізму вирішення соціальних проблем: кінець XVIII ст., Англія (Ноттінгем, Глазго, Брістоль, Лідє, Лондон) - тематичні лекції для дорослих робітників, дискусійні клуби, недільні школи, «мандрівне» і «взаємне» навчання, бібліотеки, розширені університети, класи самоосвіти; середина XIX ст., Скандинавські країни - народні університети (народні вищі школи - folk high school, folkeoplysning), М.Грунтвіг); кінець XIX - початок XX ст., Франція, Італія, Німеччина, Австро-Угорщина - народні університети (Volkshochschule, «людові університети). В Україні в різні історичні періоди також функціонувала широка мережа закладів для дорослих: в середині XIX - на початку XX ст. діяли недільні школи, курси для неписьменних, професійні курси, лекції, читальні, народні університети, народні будинки; у 20-30-ті рр. ХХ ст. - школи системи ліквідації неписьменності; робітничі й селянські школи, школи робітничої молоді, заочні загальноосвітні школи, робітфаки; 50-80-ті рр.XX ст. - вечірні школи, навчальні комбінати, школи майстрів, вечірні технікуми, вечірні та заочні факультети; народні університети, лекторії та курси, клуби, бібліотеки, музеї, гуртки, народні університети економічних і сільськогосподарських знань тощо (Тимчук, 2015).

Упродовж століть тривали пошуки змісту й форм навчання широких верств населення, які могли забезпечити поліфункціональний зміст освіти, сприяти поєднанню в освіті адекватного реальності уявлення про оточуючий світ i

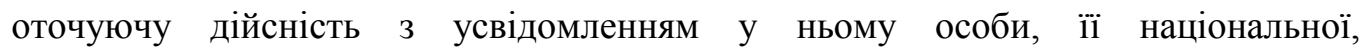
громадянської приналежності, а відтак своєчасно забезпечити загальнокультурні, особистісні, професійні, соціально-побутові інтереси і потреби людини, сприяти іiі оперативній і успішній адаптації до мінливих суспільних обставин.

У сучасних тенденціях все чіткіше простежується соціальний аспект освіти дорослих, який виявляє ii тісний взаємозв'язок i взаємозумовленість із соціальною роботою, зокрема у вирішенні таких соціальних проблем, як: боротьба з бідністю; державна безпека; гендерна політика; здоров'я і здоровий спосіб життя; конкуренція на ринку праці; перепідготовка військових; освіта для ув'язнених; нова професія для безробітних; соціальна реабілітація інвалідів; маргінальні групи населення; соціокультурне середовище й екологія; інформаційні технології та доступність інформаційних засобів; соціальне партнерство як технологія освіти дорослих і як соціальне замовлення на нову норму взаємодії в суспільних відносинах.

Для конкретного суб'єкта освіта дорослих виконує комплекс соціальних функцій, які забезпечують цілісність нового виду діяльності чи якісно новий 
рівень попередньої діяльності: адаптаційну (розуміння і прийняття нових умов життя), інформаційну (уміння знайти, вибрати, використати, створити необхідну інформацію, підвищити свою грамотність), розвивальну (дозволяє оволодівати новими способами діяльності), компенсаторну (пропонує альтернативні форми освіти) (Основы андрагогики, 2003, с.35).

Сутність адаптаційної (або адаптивної) функції освіти дорослих, за С.Архиповою, полягає у іiі спрямованості на регулювання відносин у швидкозмінному зовнішньому середовищі: перша альтернатива - основна маса громадян потребує «адаптації», «підготовки до життя», «соціально і життєво важливих навичок», тощо; друга альтернатива - демократична - підвищення освітнього і культурного рівня всього дорослого населення країни (Архипова, 2002, c.37).

Компенсаторна функція освіти дорослих традиційно розглядається як сукупність завдань 3 компенсування недоліків попередніх рівнів освіти й забезпечення балансу власної компетентності і сучасних вимог до професії. Як зазначає В.Онушкін, компенсація в освіті - це важлива умова для соціальної $\mathrm{i}$ професійної мобільності, основа вільного вибору і зміни професії у відповідності 3 індивідуальними нахилами і суспільними потребами, забезпечення необхідного динамізму і мобільності в умовах сучасного суспільства.

Розвивальна або, за визначенням В. Онушкіна і Л. Лук'янової, соціокультурна функція освіти дорослих спрямована, перш за все, на поступове збагачення діяльнісних здібностей людини та іiі духовного світу (В.Онушкін); на саморозвиток, самоорганізацію кожної особистості, на ії оновлення; на зміни та прогностичний вплив на соціальні процеси. Реалізація соціокультурної функції освіти дорослих відбувається через: оновлення інтелектуального та інформаційно-технологічного аспектів освіти; духовно-практичне усвідомлення дійсності; накопичення і відтворення професійних i суспільних цінностей (політичних, правових, моральних тощо) для підвищення якості життя людини; обмін кроскультурними освітніми ініціативами; міжсуб'єктну андрагогічну взаємодію (Лук'янова, 2010, с.6-12).

С.Архипова розглядає ще соціально-терапевтичну функцію, яка визначає спрямованість освіти дорослих на соціальну ідентифікацію, ресоціалізацію, адаптацію до нових життєвих обставин, на оволодіння знаннями і уміннями, які допоможуть подолати соціальний i психічний дискомфорт. Ця функція проявляється в тому, що дає життєвий імпульс людям похилого віку, «підказує» сенс життя людям 3 обмеженими можливостями, виліковує комплекси неповноцінності, які виникають у людей із самих різних причин; у кризових ситуаціях освіта виводить із стану депресії, пропонує вихід із складної ситуації (Архипова, 2002, с.38). 
Автори колективної монографії за ред. А. Василюк та А. Стоговського розглядають соціально-адаптаційну функцію освіти дорослих, яка виявляється у ії здатності оперативно реагувати на соціальні проблеми та негаразди шляхом прискорення соціальної адаптації різних категорій населення. Рефлексуючи над сучасними тенденціями освіти дорослих, вчені простежують радикальні зміни у інтерпретаціях сутності освіти дорослих: якщо у середині XX ст. переважала компенсаційно-адаптаційна функція освіти дорослих, то в останніх десятиліттях XX ст. ця функція набула інтегрального характеру через технічні та соціальні перетворення та посилення динаміки процесів і явищ навколишнього світу (Освіта дорослих, 2017, с.5). Почав формуватися новий підхід до освіти дорослих як до сфери можливостей у працевлаштуванні, зміни професій тощо. Найголовнішою стала вимога «навчитися вчитися».

Відповідно до соціальних функцій освіти дорослих науковці Т.Браже, Н. Василенко, В. Вершиніна, І. Колесникова, А. Марон та ін. розрізняють такі іiі види й форми: додаткова або розвиваюча (спрямована на задоволення духовних запитів особистості, потреб творчого росту), компенсаторна (передбачає заповнення пробілів у базовій освіті), адаптуюча (оперативна підготовка й перепідготовка в умовах виробничої і соціальної ситуації, що постійно змінюються), випереджаюча. За характером зв'язку з раніше одержаною освітою диференціюють постбазову, модернізуючу, «освіжаючу», відновлюючу освіту дорослих (Основы андрагогики, 2003, с.180).

Забезпечення гарантованого доступу до професійної освіти (перекваліфікації) будь-якого рівня - це одна 3 дієвих форм захисту права людини на гідний рівень життя. Однак у сфері освіти, де формуються ринкові відносини населення виступає в ролі споживача освітніх послуг тільки у випадку платіжноспроможності. Доросла людина, яка перебуває в кризовій ситуації зазвичай не має матеріальної можливості оплачувати якісні освітні послуги. Коло замикається. Без соціальної підтримки значна частина населення не здатна скористатися необхідними освітніми послугами, а значить, розв’язати багато важливих життєвих проблем.

Призначення освіти дорослих полягає у перетворенні внутрішнього світу як своєчасної і адекватної реакції-відповіді на зміни зовнішнього середовища. Неготовність людини успішно розв'язати першочергові проблеми занурює іï в кризову ситуацію, вийти $з$ якої самостійно майже неможливо. Наслідками стають втрата роботи, безробіття, професійна декваліфікація; зниження життєвого рівня; морально-психологічний дискомфорт, невпевненість у власних силах, втрата життєвих перспектив, психологічний стрес.

Сьогодні в Україні за ознакою соціальної вразливості або незахищеності, згідно $з$ діючим нормами, загалом налічується 45 категорій громадян. Серед них - 
громадяни похилого віку, інваліди та члени їх сімей, безробітні та тимчасово непрацюючі громадяни, сільські жителі, бездомні громадяни, звільнені в запас військовослужбовці, мігранти та ін.

Для різних соціальних груп населення, які потребують соціальної підтримки, розробляються особливі моделі освіти, які передбачають реалізацію як освітніх, так і специфічних функцій, а саме адаптації, ресоціалізації, підтримки.

Освіта дорослих в Україні наразі не функціонує як окрема, самостійна сфера освітніх послуг. У чинній системі освіти функціонують ланки, які пов'язані 3 формальною освітою дорослих (загальна середня освіта в різних формах, професійно-технічна, базова i повна вища освіта, післядипломна освіта аспірантура, докторантура, підвищення кваліфікації та перепідготовка). Також діє мережа закладів неформальної освіти дорослих - професійно спрямовані та загальнокультурні курси навчання найрізноманітніших форм (Концепція, 2011).

Неформальна освіта дорослих активно набуває поширення останніми роками. Ïї розвиток спрямований на впровадження ідеї освіти впродовж життя, що передбачає врахування конкретних освітньо-культурних потреб різних соціальних, професійних, демографічних та інших груп населення. Така освіта здійснюється в освітніх установах або громадських організаціях, під час індивідуальних занять і зазвичай не підтверджується наданням офіційно визнаного документа. Неформальна освіта дорослих $є$ варіативною, здійснюється у контексті навчально-просвітницьких ініціатив, поширених в усіх регіонах (просвітницьких центрах, університетах, клубах, будинках культури, музеях, бібліотеках, студіях, школах, ремісничих майстернях (зокрема, і при церквах різних релігійних конфесій) та ін.), і спрямовується на розвиток додаткових умінь і навичок різних категорій дорослих. Набули поширення мистецький, оздоровчий, мовно-лінгвістичний, інформаційно-комунікаційний, психологічно орієнтований, реабілітаційний та інші напрями. Зростає увага до проведення тренінгів, майстеркласів з особистісного й професійного розвитку різних категорій дорослих та ін.

Розширюється коло провайдерів освітніх послуг із формальної і неформальної освіти дорослих. В усіх регіонах України створено осередки освіти для різних категорій дорослого населення. Вони функціонують як самостійні інституції, так і підрозділи загальноосвітніх, професійних, вищих навчальних закладів, бібліотек та ін.

Важливою є організація навчання безробітного і незайнятого населення. 3 урахуванням досвіду інших країн сформована мережа відділень служб зайнятості та організовано навчання безробітних на базі діючих закладів освіти і спеціалізованих навчальних центрів. Навчання на робочому місці знаходиться в центрі уваги роботодавців, об'єднань наймачів і профспілок. Як правило, 
фінансуються пропоновані ними програми 3 коштів роботодавців та внесків учасників.

Велику просвітницьку роботу, особливо в сфері культури, ведуть будинки культури, бібліотеки та клуби. Їх навчальна діяльність, як правило, не відокремлена від інших напрямків роботи. Помітною і резонансною, наприклад, $є$ діяльність Відкритого університету для дорослих на базі Чернівецької обласної універсальної наукової бібліотеки ім. М. Івасюка, започаткованого благодійним фондом «Суспільні ресурси та ініціативи» в рамках міні-проекту «Освіта заради змін» (реалізується в межах проекту «Замінимо мури відчиненими вікнами» ІДЦ «Інтеграція та розвиток» та DVV International за підтримки Міністерства закордонних справ Німеччини).

Розвиток широкого спектру соціальних i громадянських компетенцій підтримується освітньою діяльністю неурядових організацій, програми навчання і просвіти яких адресовані соціально незахищеним категоріям громадян (біженцям, безробітним, багатодітним сім'ям, неблагополучним підліткам), а також іншим професійним і соціальним групам (вчителям, студентам та ін.).

Тематичний спектр пропонованих для дорослих освітніх програм досить широкий: додаткові професійні кваліфікації, розвиток соціальних i загальногромадянських компетенцій, права людини, проблеми економіки, політики, національної культури, гендерних відносин, екології та ін.

Дедалі більшої популярності набуває неформальна освіта осіб третього віку, актуальність якої передусім зумовлена старінням нації (кожен п’ятий українець — літня людина у віці від 60 років і старше). Система освіти людей третього віку $\epsilon$ показником рівня розвитку соціально-культурного, морального, наукового, технічного потенціалу країни. Життєва та освітня компетентності населення третього віку дозволяє розвиненим країнам підтримувати свою конкурентоспроможність на міжнародній арені, підвищувати інтелектуальний i соціальний рівень населення, гарантувати його професійну самореалізацію.

Заклади для старших дорослих в характеризуються розмаїттям освітніх послуг (Школа людей поважного віку при Історично-мистецькому центрі «Стара Школа» (с. Тарасівка, Києво-Святошинський район Київської обл.), Клуб для людей третього віку «Друга молодість» (м. Ірпінь, Київська обл.) та ін.). Започатковані т.з. університети третього віку, які функціонують як з ініціативи громадських, в т.ч. релігійних, організацій (наприклад, Чернівецький Університет Третього віку iм. А. Кольпінга), так і за державної підтримки - як соціальна послуга для осіб поважного віку (наказ Міністерства соціальної політики України від 25.08.2011 p. №326 «Про впровадження соціально-педагогічної послуги «Університет третього віку»»»). 
Освіта дорослих використовується як важливий ресурс у роботі з внутрішньо переміщеними особами (ВПО), поява яких спричинена відомими подіями останніх років, коли внаслідок анексії Росією Автономної Республіки Крим та втрати Україною контролю над частиною території Донецької та Луганської областей в нашій державі з'явилися великі потоки людей, які були змушені залишити місця свого постійного проживання і переселитись до інших регіонів України.

Варто зазначити, що в Україні налагоджується системна робота $з$ організації неформальної освіти для дорослих переселенців. Зокрема, в кожній області/місті діють програми підвищення кваліфікації та перепідготовки новоприбулих осіб відповідно до потреб ринку праці України; створюються центри підтримки таких громадян для надання їм консультації і психологічної підтримки в період адаптації, отримання освіти; забезпечуються умови для гуртування переселенців 3 метою спільного подолання труднощів адаптаційного періоду.

Напрацьований позитивний досвід проведення різноманітних курсів, як таких, що допомагають підвищити професійні навики, просунути по кар'єрних щаблях чи отримати більший дохід, так і таких, які просто дозволяють спілкуватися, знаходити розраду для душі, розширювати коло друзів.

Популярними є різноманітні бізнес-проекти, які надають переселенцям нові унікальні можливості пройти бізнес навчання, започаткувати власну справу в місті свого проживання, розвинути малий або середній бізнес.

Наприклад, в Чернівцях 32015 року регулярно проводиться тренінгове навчання з розширення підприємницької діяльності для внутрішньо переміщених осіб зі Сходу та Криму. Учасниками тренінгу є переселенці, які вже мають навики підприємництва. Навчання здійснюється в рамках проекту «Покращення умов життя та соціальна адаптація внутрішньо переміщених осіб в Чернівецькій області» за фінансової підтримки Свропейського Союзу.

У різних регіонах України з 2016 року Міжнародною неприбутковою організацією РН Inrenational i Харківським громадським центром «Молодь за демократію» за підтримки Посольства США в Україні i фінансування Державного департаменту США для переселенців реалізується програма «Приступаючи до справи: ділова англійська мова та основи ведення власної справи». Програма має на меті надання навчальної допомоги внутрішньо переміщеним особам, які постраждали від російської агресії у АР Крим і окремих районах Донецької і Луганської областей, започаткували власну справу чи іншій вид самозайнятості (наприклад, працюють за договорами цивільно-правового характеру) 3 метою вирішення складних економічних обставин, у яких вони опинились. Програма передбачає 90 годин безкоштовних тренінгових курсів підприємцям-початківцям, що відкрили власну справу й розглядають 
самозайнятість як вихід з кризової ситуації. Ці курси включають як оволодіння основами ділової англійської мови, так і оволодіння іншими знаннями i навичками, які стануть у нагоді на сучасному високотехнологічному ринку праці і послуг; також проводяться курси 3 нормативних вимог у сфері ведення власної справи, звітування контролюючим органам, електронної звітності і роботи з вебсайтами, у соціальних медіа, мобільних і цифрових додатках (Навчання для переселенців).

Влітку 2017 року в Дніпропетровській області за підтримки МЗС Республіки Польща розпочалася реалізація «Програми професійного навчання та розвитку підприємництва для вимушених переселенців», що передбачає індивідуальні гранти ВПО в рамках програми професійної освіти та розвитку підприємництва, за якими вони мають можливість отримати безкоштовну освіту на курсах з таких затребуваних спеціальностей, як «менеджер 3 продажів», «Бухгалтерський облік + програма 1C: Бухгалтерія», «Перукар-універсал», «Графічний дизайнер (дизайн друкованої продукції, логотипів, промоакцій)», «Веб-дизайнер» тощо (Програма професійного навчання).

У вересні 2017 р. Міністерство 3 питань тимчасово окупованих територій і внутрішньо переміщених осіб України та Німецька асоціація міжнародного співробітництва (GIZ) заявили про початок розробки спільної програми перекваліфікації внутрішньо переміщених осіб згідно з потребами ринку праці. 3 ініціативи німецької сторони розпочата підготовка програми «Професійна допомога ВПО при виході на ринок праці», що передбачає професійні курси, а також курси перекваліфікації ВПО у відповідності 3 потребами ринку праці регіонів, у яких вони проживають. У цілому, проект передбачає три напрямки, зокрема, короткострокові підготовчі курси, довгострокові курси перепрофілювання людей, які вже мають певну кваліфікацію, інноваційний напрям, що передбачає об'єднання зусиль держави, місцевої влади, підприємців та громадськості в пошуках вирішення проблем працевлаштування внутрішньо переміщених осіб. Проект реалізується за фінансової підтримки уряду Німеччини, розрахований на чотири роки і призначений для впровадження в Харківській, Донецькій, Луганській, Запорізькій та Полтавській областях. На поточний момент вже працюють курси з шиття і програма навчання за напрямом «Менеджмент проектів».

\section{Висновки}

Орієнтована на професійно-особистісне становлення людини у процесі ціложиттєвого навчання, освіта дорослих розширює можливості й створює умови для постійного самовдосконалення та оволодіння комплексом знань і умінь, 
необхідних для активної життєвої позиції особистості, іiі успішної адаптації у суспільстві, що невпинно змінюється і розвивається.

В Україні діють освітні програми для дорослих, адресовані соціально незахищеним категоріям громадян (біженцям, безробітним, багатодітним сім'ям, неблагополучним підліткам), а також іншим професійним і соціальним групам (вчителям, студентам та ін.).Їх тематичний спектр охоплює додаткові професійні кваліфікації, розвиток соціальних і загальногромадянських компетенцій, права людини, проблеми економіки, політики, національної культури, гендерних відносин, екології та ін.

Поєднання орієнтації на суспільну користь і інтереси особистості дозволяє сфері освіти дорослих швидко і адекватно реагувати на проблемні ситуації в суспільстві, використовувати навчання як ефективний інструмент їх вирішення.

Доступність освіти дорослих для широких мас населення, орієнтація на розвиток компетентності, професійно значущих особистісних якостей, конкурентоспроможності на сучасному ринку праці, на підвищення кваліфікації чи на забезпечення перекваліфікації можуть виступати в якості надійного механізму виходу з кризових ситуацій.

Перспективи подальших досліджень. Наразі тривають пошуки ефективних і оптимальних організаційно-змістових засад та механізмів освіти дорослих, здатних реалізувати соціальну політику захисту прав людини, забезпечення гідного рівня життя, сприяння адаптації населення до нових соціальноекономічних умов та ін.

\section{Література}

Архипова, С. П. (2002). Основи андрагогіки : навч.посібник, Черкаси Ужгород, $184 \mathrm{c.}$

Архипова, С. П. (2017). Теоретико-методичні основи освіти соціально незахищених категорій дорослих: автореф. дис. ... д. пед. наук;, Черкаси, 40 с.

Гамбургская декларация об обучении взрослых. Пятая Международная конференция по образованию взрослых, ЮНЕСКО. Гамбург, Германия, 14-18 июля 1997 г., www.znanie.org/pravo/document.html.

Колесникова, И. А., Марон, А. Е. \& Тонконогая, Е.П. и др. (2003). Основы андрагогики; под ред.И.А.Колесниковой, М., 240 с.

Концепція освіти дорослих в Україні, укл. : Л. Б. Лук'янова, Ніжин, 2011.

Лук'янова, Л. Б. (2010). Соціокультурна функція освіти дорослих у сучасному суспільстві, Вісник Черкаського університету, вип.183, С.6-12.

Навчання для переселенців: ділова англійська та основи ведення власної справи. (2019). http://legalspace.org/ru/romski-poseredniki-u-sferi-okhoroni-zdorov- 
ya/item/10471-pereselentsiv-navchat-dilovoi-anhliiskoi-ta-osnov-vedennia-vlasnoisрrаvую

Освіта дорослих у перспективі змін: інновації, технології, прогнози: колективна монографія; за ред. А. Василюк, А. Стоговського. (2017). Ніжин, 248 c.

Програма професійного навчання та розвитку підприємництва для вимушених переселенців, які проживають у Дніпропетровській області https://adra.org.ua/uk/novini/programa-grantiv-dlya-vpo-nova-profesiya-dlyapereselentsiv/

Рошер, В. (1895). Система призрения бедных и мероприятия против бедности, Черкассы, 135 с.

Тимчук, Л. І. (2016). Становлення та розвиток андрагогіки як теорії і практики освіти дорослих в Україні : автореф. дис. д. пед. наук, Тернопіль, 38 с. 


\title{
ADULT EDUCATION POTENTIAL IN THE SOCIAL WORK
}

\author{
Liudmyla Tymchuk, Doctor of Science (Pedagogic), Professor, Pedagogy and Social \\ work Department, Yuriy Fedkovych Chernivtsi National University, Chernivtsi, \\ Ukraine.
}

\begin{abstract}
Khrystyna Mykyteychuk, assistant, Yuriy Fedkovych Chernivtsi National University, Chernivtsi, Ukraine.
\end{abstract}

\begin{abstract}
Adult education is intended to expand the opportunities for an individual lifelong learning and to create conditions for its continuous selfimprovement and mastering the complex of knowledge and skills necessary for an active life position expressed in effective professional and social activity.

Adult education is considered as a resource of social work i.e. a kind of activity to assist the population various segments during a crisis period, which contributes to ensuring social peace and balance in society, preventing social conflicts, and neutralizing destabilizing factors. Adult education is one of the most effective ways of protecting human rights to a living decent standard, since it guarantees access to any level of the vocational education.

Adult education performs a complex of social functions that ensure the new activity integrity or the qualitatively new level of previous activity: adaptive, informative, developmental, and compensatory. Accordingly, the following kinds of adult education are distinguished: additional or developing (satisfaction of the individual spiritual requests, the creative growth needs), compensatory (filling of gaps in basic education), adaptive (operational training and retraining in the conditions of constantly changing industrial and social situation), advanced.

The adult education social functions are implemented through a network of formal education institutions (general secondary education in various forms, vocational and higher education, postgraduate education, advanced training and retraining) and nonformal adult education (professionally oriented and general cultural educational courses of various forms).

Nowadays there are educational programs for adults addressed to socially vulnerable categories of citizens in Ukraine (refugees, unemployed, large families, disadvantaged adolescents) as well as other professional and social groups (teachers, students, etc.). Their thematic spectrum covers additional professional qualifications,
\end{abstract}


social and civil competences development, human rights, problems of economy, politics, national culture, gender relations, ecology, etc.

Keywords: social work; adult education; formal education; informal education; adult education social functions.

\section{References}

Adult education in the prospect of change: innovations, technologies, predictions: collective monograph: monohraphiya. (2017). za red. A. Vasylyuk, A.Stohovskoho, Nizhyn, 248 p.

Arkhypova, S. P. (2002). Andragogy fundamentals: tutorial. Cherkasy -Uzhhorod, $184 \mathrm{p}$.

Arkhypova, S. P. (2017). Theoretical and methodological foundations in education of the adult's socially unprotected categories: author's abstract. diss. ... ped. sciences. Cherkasy, $40 \mathrm{p}$.

Hamburg Declaration on Adult Education. Fifth International Conference on Adult Education, UNESCO. Hamburh, Hermanyya, 14-18 yyulya 1997 , www.znanie.org/pravo/document.html

Kolesnykova, Y. A., Maron, A. E. \& Tonkonohaya, E. P. (2003). Andragogy fundamentals, y dr.; pod red.Y.A.Kolesnykovoy, M., 240 p.

Luk'yanova, L. B. (2010). Socio-cultural function of adult education in modern society. Visnyk Cherkaskoho universytetu, Vol.183, P.6-12.

Lukyanova, L. B. (2011). The adult education concept in Ukraine., Nizhyn.

Rosher, V. (1895). The care system for the poor and activities against poverty], Cherkassy, $135 \mathrm{p}$.

The program of vocational training and entrepreneurship development for forced migrants who live in Dnipropetrovsk region. (2019). https://adra.org.ua/uk/novini/programa-grantiv-dlya-vpo-nova-profesiya-dlyapereselentsiv/

Training for migrants: Business English and the basics of running business. http://legalspace.org/ru/romski-poseredniki-u-sferi-okhoroni-zdorov-ya/item/10471pereselentsiv-navchat-dilovoi-anhliiskoi-ta-osnov-vedennia-vlasnoi-spravy

Tymchuk, L. I. (2016). Andragogy formation and development as the theory and practice of adult education in Ukraine: avtoref. dys. d. ped. nauk, Ternopil, 38 p. 